\title{
Effects in Blended Classes on Operations Research by the Practice
}

\author{
Isao Miyaji \\ Faculty of Informatics, Okayama University of Science, Japan
}

\begin{abstract}
Operations Research classes are held focusing on practice. Following the textbook, slides are shown, there are lectures on problems. Their formularization and solutions are explained using examples. After classes, as practice, a sheet with blank boxes for answers to similar problems in the same format as the examples was distributed and students were asked to complete it. The next week, after giving the answers to the practice problems, a sheet with problems similar to examples and practice was distributed as a challenge in the same format as practice problems and students were asked to complete it. E-learning that makes it possible to study with lecture slides and to browse answers to practice problems was provided for lesson preparation and revision in and outside of classes. At the beginning and the end of the course, students were questioned about their level of term recognition and awareness in the classes. This information is analyzed. In this paper, Changes in level of term recognition and awareness, and useful activities for improving awareness are reported. General awareness and awareness related to subject are compared for groups of students that are categorized on the basis of cluster analysis that uses ability awareness. The mean growth is compared for groups of awareness that are categorized through principal component analysis that uses awareness rating value.
\end{abstract}

\section{Introduction}

In Operations Research (OR) classes as one type of information science lectures, we believed that the contents of classes would not be well understood with only explanations of and solutions to problems. Therefore, we incorporated practice into these classes. The contents of the textbook were explained. During practice, worksheets that made it possible to practice by filling in the blanks were distributed. As a result, almost all students did the practice sheets and handed them in. For the practice portions of all chapters, the calculation method was explained so that it was possible for students to obtain solutions if they filled in the appropriate figures in each box of the calculation formula. It was made clear to students that if they had a calculator, they would be able to solve OR problems themselves. This method was adopted with the expectation of understanding the nature of OR and fostering people who can solve problems that they come up against in society through the experience of solving problems. The contents of these lectures have been made into an Operations Research textbook [1].

Following the textbook, slides are shown, there are lectures on problems and their formularization, and solutions are explained using examples in these classes. After these classes, a sheet with blank boxes for answers to similar problems in the same format as the examples was distributed and students were asked to complete it as practice. After giving the answers to the practice problems at the next week, a sheet with problems similar to examples and practice was distributed in the same format as practice and students were asked to complete it. In this way, OR classes were conducted focusing on practice [2].

How to learn is different for each student. A perfect media for all students does not exist. It is possible to support many and various student learning styles and to deepen understanding by using more than one media [3] [4]. The use of e-learning, which cooperates with and expands the class, in the classroom is a useful means to improve the traditional class [5] [6]. Reading class content on the web increases opportunities to review and prepare. It is tied with settlement of the contents to learn many times until a learner is convinced. Even if a learner is absent from a class, the class content can be reviewed at his/her convenience.

Approximately $80 \%$ of classes using e-learning in Japanese higher education are blended learning [7]. In Japan, the number of blended classes coordinating lectures and e-learning is particularly high. These are producing effects on studying through reciprocal complementation of lectures and e-learning [8]. There are expectations for this type of blended classes [9]. The authors have been implementing blended learning for the past ten years or so and have produced good results [10]. The authors are implementing blended classes for an introduction to computers. We can report that there were positive results from the development of classes with integrated media such as organized lecture notes, elearning and short tests. In addition, we reported that it was possible to even further boost effects due to an increase in interaction with teachers through a questionnaire about the level of understanding [11]. The results of a comparison of the use of e-learning in and outside of classes showed that almost the same 
effects could be obtained with both methods [12] [13].

The structure of the classes can be roughly divided into lecture, practice and experiment. Blended classes for which we have made reports up until now have been lecture-type classes. Accordingly, in Operations Research classes that are practice-type, in order to produce results by implementing blended classes, preparing e-learning that makes it possible to study with the lecture slides and to browse answers to practice problems made it possible to use e-learning in lesson preparation and revision in and outside of classes.

The effects of blended practice-type classes were discovered by analyzing the answer to questionnaire survey about their level of recognition of terms used in the classes and awareness at the beginning and end of the course. Awareness and activities are classified into some clusters by implementing cluster analysis, respectively. $\chi^{2}$ test and residual analysis are conducted for contingency table constructed by two kinds of clusters. The result showed a significant deviation on the frequency. As the results, we know useful activities for improving awareness. General awareness and awareness related to subject are compared for groups of students that are categorized on the basis of cluster analysis that uses ability awareness. The mean growth is compared for groups of awareness that are categorized through principal component analysis that uses awareness rating value.

\section{Class Design and Contents}

Class contents are shown in Table 1. The textbook is composed of 14 chapters with representative OR techniques and in classes, the 7 problems shown in Table 1 rom these 14 chapters were taken up [1]. The target was an elective course for the latter period of the 3rd year of university information studies. There were 20 students in the 2012 class. There were a total of 15 classes of 90 minutes each.

The textbook is composed of goals, definitions of problems, solutions to problems, practice and challenges for each technique. It was assumed that they would be used in lectures, but at the beginning of each chapter, the goal was explained so that they could also be used in practice and experiments. Next, the problems in the chapter were explained and defined so that the students understood the content. Actual examples were used and there were no omissions, giving a detailed explanation of techniques and methods or the solution to the problem. After this, practice problem sheets were distributed and practice in actually calculating and solving problems similar to the examples was conducted. These problems can be solved with either a calculator or a pen and paper. At this time, the practice problems sheet is prepared with the required tables and text and is in a framework in which the problem can be solved by filling in figures and results in the blanks. Furthermore, two challenges are also in the textbook to offer an opportunity for practice for those who wish to further cultivate their understanding. This is a feature that does not exist in similar books.

If the problems could not be completed within the time limit, students were instructed to finish and hand it in by the next week. The answers to practice questions were explained the following week. One of the ways of using these challenges is to distribute challenge sheets with the same format as for practice and have the students solve them. Students were made to hand these practice and challenge sheets in as many times as it took until they got the correct answers. Furthermore, final exams were implemented. In any case, understanding of each technique is improved by repeatedly solving three types of problems: the example problem that shows the solution method, the practice problem and the challenge. From the actual experience of giving lectures, the explanation of goals, problem definition and problem solution took between 15 and 40 minutes so it was possible to use between 35 and 60 minutes for practice, ensuring plenty of time [2]. Lectures, practice and challenges for one chapter were completed every two weeks. At the beginning of the class, the answers to the previous week's practice are given. Then, after explaining the goal of problem technique on that day, the formulization and method for solving the problem are explained. Lecture contents are explained through slides projected on the screen. After that, a practice sheet with blanks is distributed in order to implement practice for the chapter that has been explained. Then the students are asked to solve the problems. When the problems are solved, the students hand them in.

\subsection{Class Goals and Aims}

OR is a mathematical model for decision-making. Many mathematical models are proposed. The goal of this class is to explain these techniques, to actually practice these techniques after the lecture, to cultivate understanding and to be useful in problem solving in society. In addition, through various activities in these lectures, the ability to think and solve problems is cultivated.

The aims of this class are to understand the selected mathematical models in OR and the algorithms of these techniques so that students can solve the problems according to these algorithms.

\subsection{Class Design}

Explanations were given based on the class planning and design in Table 1. In the first week, class plan explanations were distributed and class 
planning was explained. After that, an initial survey of term recognition and awareness was conducted. Based on the textbook, the goals, problem definition and solution method for the example were explained for Chapter 4 Transportation. Next, practice sheets were distributed and students were asked to solve the practice problems referring to the explanation of the solution method for the example. At that time, students were given advice to browse the e-learning lecture slides and refer to them. During practice, the teacher went around the classroom and accepted a question. Students were observed helping each other. Those who came up with the answers were asked to submit their practice sheets. Those who did not come up with the answers were asked to bring their completed practice sheets to the professor's office before the next class.

The next week, the answers to the practice problems were given. After that, sheets were handed back to those who had made mistakes in the answers or the calculations. Next, challenge sheets were distributed and students were asked to solve the problems. At that time, the students were advised to browse the e-learning lecture slides and refer to them. Those who came up with the answers were asked to submit their challenge sheets. Those who did not come up with the answers were asked to bring their completed challenge sheets to the professor's office before the next class.

In the 3 rd week, the goals, problem definition and solution method for the example were explained for Chapter 5 Allocation. Next, the students were asked to solve practice problems in the same way as for Chapter 4 and submit them. In the 4 th week, the students were asked to solve challenge problems in the same way as for Chapter 5 and submit them. In this way, the class got through one chapter every 2 weeks.

The submission of practice and challenge problems was repeated until the answer was correct.
If a problem sheet was to be given back, mistakes on the sheet were marked with a colored pencil. There were some students who took a long time to get the right answers even though they were able to browse e-learning documents after the answers were explained in class. In the end, 7 practice and challenge problems were completed in 15 weeks. Post surveys of term recognition and awareness were taken in the 15 th week.

Students were asked to fill in the goals, problem definition and discussion for each chapter after downloading framework files and were asked to submit these two reports in the 8th and the 14th weeks.

\subsection{Contents of E-Learning}

To intensify the effect of this lecture and to enable the students to make a peer assessment, elearning functions were added as follows: (1) learning with 254 lecture slides; (2) learning with downloadable documents and templates of seven kinds; (3) submitting and uploading exercises of seven kinds; (4) uploading opinions to a bulletin board and browsing them; and (5) sending question mail.

\section{Analysis Results and Discussion}

For this paper, in order to understand the level of understanding of terms that came up in class contents, term recognition surveys were conducted before and after the course. By conducting study activities related to the classes, an awareness study related to ability was implemented before and after the course in order to understand the changes in awareness related to ability. In order to understand which

Table 1. Plans and design on Operations Research class

\begin{tabular}{|c|c|c|c|c|c|c|c|c|c|c|c|c|}
\hline \multirow[b]{2}{*}{ 岕 } & \multirow[b]{2}{*}{$\begin{array}{l}\text { Lecture } \\
\text { Contents }\end{array}$} & \multicolumn{7}{|c|}{ During the Class } & \multicolumn{4}{|c|}{ Outside the Class } \\
\hline & & $\begin{array}{l}\text { Lecture } \\
\text { Slides }\end{array}$ & $\begin{array}{l}\text { Practice } \\
\text { Slides }\end{array}$ & $\begin{array}{l}\text { Practice } \\
\text { Sheets }\end{array}$ & $\begin{array}{c}\text { Challenge } \\
\text { Sheets }\end{array}$ & $\begin{array}{c}\text { Instruction } \\
\text { for Class } \\
\text { Plan and } \\
\text { Method }\end{array}$ & $\begin{array}{l}\text { Awarenes } \\
\text { s Survey }\end{array}$ & $\begin{array}{l}\text { Recognitio } \\
\text { n Survey }\end{array}$ & $\begin{array}{l}\text { Lecture } \\
\text { Slides }\end{array}$ & $\begin{array}{l}\text { Practice } \\
\text { Slide } \\
\text { Study }\end{array}$ & $\begin{array}{l}\text { Evaluation } \\
\text { Sheets }\end{array}$ & $\begin{array}{c}\text { Report } \\
\text { Framewor } \\
k\end{array}$ \\
\hline 1 & $\begin{array}{l}\text { Ch. } 4 \\
\text { Transportatio } \\
\text { n }\end{array}$ & $\begin{array}{c}\text { Chapter } \\
4\end{array}$ & & $\begin{array}{c}\text { Practice } \\
1\end{array}$ & & $\begin{array}{c}\text { Distributio } \\
n \text { of } \\
\text { Materials }\end{array}$ & $\begin{array}{l}\text { Survey } \\
\text { prior to } \\
\text { course }\end{array}$ & $\begin{array}{l}\text { Survey } \\
\text { prior to } \\
\text { course }\end{array}$ & $\begin{array}{c}\text { Chapter } \\
4\end{array}$ & & $\begin{array}{l}\text { Submit } \\
\text { prior to } \\
\text { course }\end{array}$ & \\
\hline 2 & Challenge 1 & & $\begin{array}{l}\text { Practice } \\
\text { Answer } 1\end{array}$ & & $\begin{array}{c}\text { Challenge } \\
1\end{array}$ & & & & & $\begin{array}{c}\text { Practice } \\
\text { Answer } 1\end{array}$ & & \\
\hline 3 & $\begin{array}{l}\text { Ch. } 5 \\
\text { Assignment }\end{array}$ & $\begin{array}{c}\text { Chapter } \\
5\end{array}$ & & $\begin{array}{c}\text { Practice } \\
2\end{array}$ & & & & & $\begin{array}{c}\text { Chapter } \\
5\end{array}$ & & & \\
\hline 4 & Challenge 2 & & $\begin{array}{l}\text { Practice } \\
\text { Answer } 2\end{array}$ & & $\begin{array}{c}\text { Challenge } \\
2\end{array}$ & & & & & $\begin{array}{l}\text { Practice } \\
\text { Answer } 2\end{array}$ & & \\
\hline 5 & $\begin{array}{l}\text { Ch. } 6 \text { Travell- } \\
\text { ing Salesman }\end{array}$ & $\begin{array}{c}\text { Chapter } \\
6\end{array}$ & & $\begin{array}{c}\text { Practice } \\
3\end{array}$ & & & & & \begin{tabular}{|c|} 
Chapter \\
6
\end{tabular} & & & \\
\hline 6 & Challenge 3 & & $\begin{array}{c}\text { Practice } \\
\text { Answer } 3\end{array}$ & & $\begin{array}{c}\text { Challenge } \\
3 \\
\end{array}$ & & & & & $\begin{array}{c}\text { Practice } \\
\text { Answer } 3\end{array}$ & & \\
\hline 7 & $\begin{array}{l}\text { Ch. } 7 \\
\text { Sequencing }\end{array}$ & $\begin{array}{c}\text { Chapter } \\
7\end{array}$ & & $\begin{array}{c}\text { Practice } \\
4\end{array}$ & & & & & $\begin{array}{c}\text { Chapter } \\
7\end{array}$ & & & \\
\hline 8 & Challenge 4 & & $\begin{array}{l}\text { Practice } \\
\text { Answer } 4\end{array}$ & & $\begin{array}{c}\text { Challenge } \\
4\end{array}$ & & & & & $\begin{array}{l}\text { Practice } \\
\text { Answer } 4\end{array}$ & & $\begin{array}{c}\text { No.1 (Chs } \\
4,5,6,7)\end{array}$ \\
\hline 9 & $\begin{array}{l}\text { Ch. } 8 \\
\text { Shortest Path }\end{array}$ & $\begin{array}{c}\text { Chapter } \\
8 \\
\end{array}$ & & $\begin{array}{c}\text { Practice } \\
5 \\
\end{array}$ & & & & & \begin{tabular}{|c|} 
Chapter \\
8 \\
\end{tabular} & & & \\
\hline 10 & Challenge 5 & & $\begin{array}{l}\text { Practice } \\
\text { Answer } 5\end{array}$ & & $\begin{array}{c}\text { Challenge } \\
5\end{array}$ & & & & & $\begin{array}{l}\text { Practice } \\
\text { Answer } 5\end{array}$ & & \\
\hline 11 & $\begin{array}{l}\text { Ch. 9 Sched- } \\
\text { ule Planning }\end{array}$ & $\begin{array}{c}\text { Chapter } \\
9\end{array}$ & & $\begin{array}{c}\text { Practice } \\
6\end{array}$ & & & & & $\begin{array}{c}\text { Chapter } \\
9\end{array}$ & & & \\
\hline 12 & Challenge 6 & & $\begin{array}{l}\text { Practice } \\
\text { Answer } 6\end{array}$ & & $\begin{array}{c}\text { Challenge } \\
6\end{array}$ & & & & & $\begin{array}{l}\text { Practice } \\
\text { Answer } 6\end{array}$ & & \\
\hline 13 & $\begin{array}{l}\text { Ch. } 10 \\
\text { Replacement }\end{array}$ & $\begin{array}{c}\text { Chapter } \\
10\end{array}$ & & $\begin{array}{c}\text { Practice } \\
7\end{array}$ & & & & & $\begin{array}{c}\text { Chapter } \\
10\end{array}$ & & & \\
\hline 14 & Challenge 7 & & $\begin{array}{l}\text { Practice } \\
\text { Answer } 7\end{array}$ & & $\begin{array}{c}\text { Challenge } \\
7\end{array}$ & & & & & $\begin{array}{l}\text { Practice } \\
\text { Answer } 7\end{array}$ & & $\begin{array}{c}\text { No.2 (Chs } \\
8,9,10)\end{array}$ \\
\hline 15 & $\begin{array}{l}\text { Overall } \\
\text { Practice }\end{array}$ & & & & & & $\begin{array}{l}\text { Survey } \\
\text { after } \\
\text { course }\end{array}$ & $\begin{array}{c}\text { Survey } \\
\text { after } \\
\text { course }\end{array}$ & & & $\begin{array}{l}\text { Submit } \\
\text { after } \\
\text { course }\end{array}$ & \\
\hline
\end{tabular}


activities are useful in improving this awareness, students were asked to fill in activities that help to improve awareness in the right-hand column beside the awareness evaluation number in the post-project awareness survey.

Below, we state that significant differences were observed in the significance testing with a significance level of $5 \%$. The symbols $\mathrm{m}, \mathrm{SD}, \mathrm{F}, \mathrm{t}$ and $\mathrm{p}$ refer to mean, standard deviation, $\mathrm{F}$ value, $\mathrm{t}$ value for test statistics and probability respectively. The results of the tests show that symbols ***, ** and $*$ are significant with significance levels of $0.1,1$ and $5 \%$ respectively. The + symbol shows the significance trend with a significance level of $10 \%$.

\subsection{Changes in Term Recognition}

In order to find out whether students have understood the OR related terms that came up in class lectures, the term recognition level survey method developed by Nakamura et al. was used [14]. The 33 terms listed in Table 2 were surveyed twice for recognition (R) before (April) and after (July) the course $(\mathrm{N}=19)$. 19 people gave valid responses to this survey. Evaluations were made on three levels of recognition: 3. I understand it, 2. I do not fully understand it but I have heard of it, and 1. I do not understand it. H-check terms for which there is a high likelihood of respondents understanding them were: PC, queue and network and an L-check term for which there is a low likelihood of respondents understanding it was: simulation. These 4 terms were expected and set to be terms that did not change throughout the class.

Results of paired significance tests for recognition of the above-mentioned terms are shown in Table 2. The results of pre- and post- paired significance tests for the development of average recognition of the 33 terms showed a significant difference with a significance level of $0.1 \%$. It was observed that post-course recognition was higher.

The results of a paired significance tests for average growth of recognition of each term before and after the course showed a significance level of $0.1 \%$ for 22 terms, a significance level of $1 \%$ for 6 terms and a significance level of $5 \%$ for 1 term. This means that recognition levels for these 29 terms had risen after the course. However, through the significance test, 4 terms were observed not to have significant differences. These were all the check terms. PC, queue and network were $\mathrm{H}$-check terms. These had high recognition of $\mathrm{R}=3.0, \mathrm{R}=2.6$ and $\mathrm{R}=2.5$ before the course and of $\mathrm{R}=3.0, \mathrm{R}=2.8$ and $\mathrm{R}=2.7$ after the course respectively with almost no change. It is for this reason that these terms, having had high recognition from the beginning, did not change much due to the classes. In addition, the Lcheck term 'simulation' was not explained in the classes and the pre-course survey showed low recognition of $\mathrm{R}=2.1$ whereas the post-course survey showed a value of $\mathrm{R}=2.4$ with almost no change. In this way, the 4 check terms that were set to show the validity of the survey were stable and there was no significant difference in the significance test. This can be considered to show the validity of the survey. Due to this fact, it can be said that understanding of the 29 terms that appeared in relation to class contents was improved.

Table 2. Significance Test for Term Recognition

\begin{tabular}{|c|c|c|c|c|c|c|c|c|}
\hline \multirow{2}{*}{ Contents } & \multirow{2}{*}{ No. } & \multirow{2}{*}{ Term } & \multicolumn{2}{|c|}{ Before } & \multicolumn{2}{|c|}{ After } & \multicolumn{2}{|c|}{$\begin{array}{c}\text { Significan } \\
\text { ce Test }\end{array}$} \\
\hline & & & $\mathrm{m}$ & SD & $\mathrm{m}$ & SD & $\begin{array}{l}\mathrm{t}- \\
\text { value }\end{array}$ & $\mathrm{p}$ \\
\hline \multirow{6}{*}{ Transportation } & 2 & Transportation & 1.2 & 0.4 & 2.9 & 0.2 & 16.7 & $* * *$ \\
\hline & 3 & Objective Function & 1.4 & 0.5 & 2.8 & 0.4 & 9.2 & **** \\
\hline & 4 & Restrictions & 1.6 & 0.6 & 2.8 & 0.4 & 9.9 & $* * *$ \\
\hline & 5 & Optimal Solution & 1.6 & 0.7 & 2.7 & 0.4 & 5.5 & **** \\
\hline & 6 & Typical Constant & 1.3 & 0.4 & 2.5 & 0.7 & 6.7 & *** \\
\hline & 7 & Optimal Decision & 1.3 & 0.4 & 2.5 & 0.6 & 7.5 & **** \\
\hline Allocation & 8 & Allocation & 1.3 & 0.4 & 2.8 & 0.4 & 10.9 & $* * *$ \\
\hline \multirow{2}{*}{$\begin{array}{l}\text { Travelling } \\
\text { Salespeople }\end{array}$} & 9 & Travelling Salespeople & 1.2 & 0.4 & 2.7 & 0.4 & 13.6 & $* * *$ \\
\hline & 10 & Setup Fees & 1.2 & 0.4 & 2.5 & 0.5 & 8.5 & **** \\
\hline \multirow{2}{*}{ Ordering } & 13 & Ordering & 1.4 & 0.6 & 2.7 & 0.4 & 8.7 & $* * *$ \\
\hline & 14 & Johnson Method & 1.2 & 0.4 & 2.2 & 0.6 & 6.5 & *** \\
\hline \multirow{6}{*}{$\begin{array}{l}\text { Shortest } \\
\text { Route }\end{array}$} & 15 & Shortest Route & 1.6 & 0.6 & 2.7 & 0.5 & 8.4 & $* * *$ \\
\hline & 12 & Distance Matrix & 1.3 & 0.4 & 2.6 & 0.5 & 9.8 & *** \\
\hline & 16 & Node & 1.8 & 0.6 & 2.6 & 0.6 & 3.5 & ** \\
\hline & 17 & Arc & 1.5 & 0.6 & 2.4 & 0.6 & 4.5 & **** \\
\hline & 18 & Diagraph & 1.3 & 0.5 & 2.4 & 0.7 & 7.4 & $* * *$ \\
\hline & 19 & Shortest Route & 1.7 & 0.7 & 2.6 & 0.7 & 4.5 & *** \\
\hline \multirow{4}{*}{$\begin{array}{l}\text { Schedule } \\
\text { Control } \\
\text { Planning }\end{array}$} & 21 & Schedule Control Planning & 1.6 & 0.7 & 2.5 & 0.6 & 5.3 & $* * *$ \\
\hline & 22 & PERT & 1.3 & 0.4 & 2.3 & 0.7 & 6.5 & **** \\
\hline & 23 & Arrow Diagram & 1.6 & 0.7 & 2.5 & 0.6 & 3.9 & $* *$ \\
\hline & 24 & Critical Path & 2.2 & 0.7 & 2.8 & 0.4 & 3.0 & ** \\
\hline \multirow{4}{*}{ Exchange } & 25 & Exchange & 1.2 & 0.4 & 2.7 & 0.4 & 13.0 & **** \\
\hline & 26 & Discounted Value & 1.4 & 0.5 & 2.3 & 0.6 & 5.3 & **** \\
\hline & 27 & Malfunction Probability & 1.7 & 0.7 & 2.5 & 0.5 & 3.7 & $* *$ \\
\hline & 28 & Average Lifespan & 1.9 & 0.8 & 2.5 & 0.6 & 2.2 & $*$ \\
\hline \multirow{4}{*}{$\begin{array}{l}\text { Inventory } \\
\text { Control }\end{array}$} & 29 & Inventory Control & 1.5 & 0.5 & 2.3 & 0.7 & 6.4 & $* * *$ \\
\hline & 30 & Order Point Method & 1.4 & 0.5 & 2.3 & 0.5 & 6.9 & **** \\
\hline & 32 & Storage Costs & 1.5 & 0.6 & 2.2 & 0.7 & 3.6 & $* *$ \\
\hline & 33 & No. of Orders & 1.6 & 0.6 & 2.3 & 0.5 & 3.6 & ** \\
\hline \multirow{5}{*}{$\begin{array}{l}\text { Check } \\
\text { Terms }\end{array}$} & 31 & Simulation & 2.1 & 0.6 & 2.4 & 0.7 & 1.6 & \\
\hline & 20 & Network & 2.5 & 0.5 & 2.7 & 0.4 & 1.2 & \\
\hline & 11 & Queue & 2.5 & 0.5 & 2.6 & 0.5 & 0.3 & \\
\hline & 1 & PC & 2.9 & 0.2 & 2.9 & 0.2 & 0.0 & \\
\hline & & Average & 1.5 & 0.3 & 2.4 & 0.3 & 8.9 & **** \\
\hline
\end{tabular}

\subsection{Changes in Evaluation Values of Awareness related to Ability}

The 35 categories listed in Table 3 were surveyed twice for awareness before (April) and after (July) the course. There were 9 evaluation values: 1 . Not at all, 3. Slight, 5. A little, 7. Fairly and 9. Extremely. 19 people responded to this before and after the course.

Average pre- and post-course evaluation values for all 35 categories were 4.2 and 5.1 respectively. Results of paired t-tests for pre- and post-evaluation values are shown at the bottom of Table 3 . Significant differences in pre- and post-course values were observed in all 35 categories. It was discovered that awareness related to ability had improved as a whole after the course. 
The results of t-tests for pre- and post-evaluation values for each category of awareness related to ability are shown in Table 3 . The 20 categories of (2), (6), (7), (14)-(17), (20), (22)-(28) and (31)-(35) were observed to have significant differences. There were no significant difference trends for the 4 categories of (4), (8), (21) and (29). Therefore, it was discovered that awareness evaluation values were improved for these.

One of the goals of the lectures was to cultivate the ability to think and to solve problems through various activities. It can be said that evaluation values for evaluation categories (26) Ability to solve problems and (28) Ability to think which are related to this were improved.

It was discovered that all evaluation values for categories (31) to (35) related to knowledge of Operations Research improved. It is thought that by solving 3 problems in each chapter: example, practice and challenge, knowledge about OR and decision-making methods, expressing social phenomena in mathematical models, knowledge about algorithms to solve the mathematical models, and volition to solve social phenomena are increased.

Table 3. Significance Test of Awareness Related to Ability

\begin{tabular}{|c|c|c|c|c|c|c|}
\hline \multirow{2}{*}{ Awareness related to Ability } & \multicolumn{2}{|c|}{ Before } & \multicolumn{2}{|c|}{ After } & \multicolumn{2}{|c|}{$\begin{array}{c}\text { Significan } \\
\text { ce Test }\end{array}$} \\
\hline & $\mathrm{m}$ & SD & $\mathrm{m}$ & SD & $\begin{array}{c}\mathrm{t}- \\
\text { value }\end{array}$ & $\mathrm{p}$ \\
\hline (1) Interest in and curiosity about computers & 6.7 & 1.5 & 6.9 & 1.4 & 0.7 & \\
\hline (2) Understanding of computers & 4.7 & 1.6 & 5.5 & 1.3 & 2.7 & $*$ \\
\hline (3) Computer operation skills & 4.7 & 1.5 & 5.2 & 1.3 & 1.4 & \\
\hline (4) Computer usage methods and broadening of situations & 4.7 & 1.6 & 5.5 & 1.6 & 2.1 & + \\
\hline (5) Ability to set challenges, ability to discover problems & 4.3 & 1.7 & 4.6 & 1.4 & 1.1 & \\
\hline (6) Ability to plan, to do things in a planned manner & 4.1 & 1.5 & 4.8 & 1.1 & 2.8 & $*$ \\
\hline (7) Cultivation of understanding of knowledge learned & 4.5 & 1.0 & 5.2 & 1.1 & 2.9 & ** \\
\hline (8) Ability to study by oneself, ability to learn & 4.3 & 1.2 & 5.0 & 1.4 & 2.0 & + \\
\hline (9) Ability to gather information, ability to conduct research & 4.9 & 1.4 & 5.5 & 1.8 & 1.2 & \\
\hline (10) Ability to sort through related information or data & 4.4 & 1.7 & 4.9 & 1.4 & 1.2 & \\
\hline (11) Ability to analyse information & 4.5 & 1.3 & 5.1 & 1.8 & 1.3 & \\
\hline (12) Ability to express thoughts in writing & 3.9 & 1.7 & 4.4 & 1.8 & 1.7 & \\
\hline (13) Ability to express thoughts through media other than writing & 3.9 & 1.9 & 4.1 & 1.6 & 0.5 & \\
\hline (14) Ability to speak and explain things to others in an easy-to-understand manner & 3.7 & 1.9 & 4.7 & 1.9 & 4.1 & $* * *$ \\
\hline (15) Ability to make presentations & 3.9 & 2.0 & 4.6 & 2.0 & 2.6 & $*$ \\
\hline (16) Ability to listen to what people are saying and ability to ask people questions & 4.7 & 2.1 & 5.4 & 1.8 & 2.3 & $*$ \\
\hline (17) Communication ability & 4.5 & 2.3 & 5.5 & 2.1 & 2.7 & $*$ \\
\hline (18) Ability to appropriately self-evaluate one's thoughts & 4.3 & 1.6 & 4.7 & 1.6 & 2.0 & + \\
\hline (19) Ability to appropriately evaluate other people's thoughts & 4.8 & 1.8 & 5.3 & 1.5 & 1.9 & + \\
\hline (20) Ability to correct and improve on one's own thoughts & 4.5 & 1.6 & 5.1 & 1.3 & 2.6 & * \\
\hline (21) Ability to pursue matters deeply, ability to explore matters & 4.3 & 1.7 & 4.9 & 1.3 & 2.1 & + \\
\hline (22) Ability to execute, ability to practice, ability to put into action & 4.1 & 1.4 & 5.1 & 1.6 & 3.3 & ** \\
\hline (23) Ability to cooperate with others, ability to study in cooperation with others & 4.5 & 1.7 & 5.6 & 1.9 & 3.1 & ** \\
\hline (24) Sense of accomplishment, sense of satisfaction & 4.6 & 1.7 & 5.6 & 2.1 & 2.5 & * \\
\hline (25) Sense of fulfilment, sense of achievement & 4.8 & 1.7 & 5.6 & 2.1 & 2.3 & * \\
\hline (26) Ability to solve problems & 4.4 & 1.5 & 5.1 & 1.4 & 2.2 & $*$ \\
\hline (27) Ability to construct and create knowledge & 4.0 & 1.7 & 4.9 & 1.4 & 3.1 & $* *$ \\
\hline (28) Ability to think, consider and come up with ideas by oneself & 4.2 & 1.5 & 5.2 & 1.8 & 2.4 & * \\
\hline (29) Creativity/ability to create & 4.3 & 1.6 & 4.9 & 1.7 & 1.8 & + \\
\hline (30) Interest in and curiosity about this field & 4.8 & 1.8 & 5.2 & 1.6 & 1.0 & \\
\hline (31) Knowledge about Operations Research & 2.1 & 1.6 & 5.1 & 1.4 & 6.1 & $* * *$ \\
\hline (32) Knowledge about decision-making methods & 2.5 & 1.6 & 4.7 & 1.4 & 5.1 & $* * *$ \\
\hline (33) Knowledge about expressing current societal problems in mathematical models & 2.2 & 1.4 & 4.4 & 1.2 & 6.5 & **** \\
\hline (34) Knowledge about algorithms that solve mathematical models & 2.4 & 1.6 & 4.6 & 1.3 & 6.2 & **** \\
\hline (35) Volition to solve current societal problems & 3.4 & 1.5 & 4.8 & 1.5 & 3.8 & $* *$ \\
\hline Average & 4.2 & 1.2 & 5.1 & 1.2 & 4.8 & *** \\
\hline
\end{tabular}

\subsection{Cluster Analysis on Ability Related Awareness and Useful Activities that can Improve Such Awareness}

With respect to the ability related awareness survey conducted afterwards, out of pool of activities, activities that were considered useful has been entered on the right side of each awareness evaluation value. The number of entered activities was 20. The number of listed activities was 892 .
There were 19 respondents. The number of average listed activities per person was 46.9 .

Cross tabulation was created by displaying awareness as "row" and activity as "column". Main items on ability and awareness that consist large number of listed activities were "(7) better understanding of learning knowledge (frequency 36), (21) research ability (33), (8) learning ability (31), (26) problem solving ability (30), (31) knowledge on Operations Research (30)".

Activities with high number of listed frequency were "01 hearing a lecture (frequency 305), 10 
reviewing (67), 03 asking friend regarding lecture content (62), 02 hearing answers for practice problems (61), 09 to preparing for study (60), 11 studying by using textbook (59), 05 asking friend regarding practice problems (48), etc.".

Based on these findings, we have discovered that the type of activities considered useful for the educating process were listening to lecture/answers, conduct preparation/review, ask questions, etc. As you can see, the findings shows that characteristic of this class such as iteratively solving 7 types of exercise problems/topics after listening to the explaining of solution to the example problems, have proven to be useful in increasing the OR knowledge and awareness.

Since activity number per unit cell on the crosstabulation table is a small number amounting to only about 1.3 , by itself we cannot conduct $\chi^{2}$ test and therefore cannot identify activities that are useful in increasing individual awareness. With the use of cross-tabulation table, we have conducted a cluster analysis through "Ward Method" by setting "useful activity frequency" as variable and "ability and awareness items" as the case. As a result, we were able to obtain 4 clusters for awareness. Based on the dendrogram obtained, awareness has been categorized into 4 clusters (clusters I to IV) as shown on Table 4.

Cluster I consists 16 types of awareness such as " (28) ability to think, (29) ability to create, (11) ability to analyze information, (33) knowledge that can express social issues in a form of mathematical model, (34) knowledge on algorithm to solve mathematical model, (32) knowledge on decision making method, (27) ability to compose knowledge, (30) interest and concern on this area, (26) problem solving ability, (31) knowledge on Operations Research, (35) desire to solve social issues, (5) issue setting ability, (1) interest and concern toward computer, (2) ability to comprehend computer, (3) computer operation skill, (4) computer use method and scene expansion". Number of such items being listed were 400. Based on these findings, cluster I can be summarized as "I. Awareness on understanding of OR and problem solving ability".

Cluster II consists of 6 awareness which are "(24) sense of fulfillment, (25) sense of accomplishment, (22) performance ability, (8) learning ability, (21) research ability, (7) deeper understanding of knowledge gained by study". There were 177 of such items being listed. Based on these findings, cluster II can be summarized as "II. Awareness on learning and sense of satisfaction".

Cluster III consists of 9 awareness which are "(9) ability to gather information, (10) ability to sort and summarize information or data, (6) ability to plan things, (12) ability to depict in writing, (13) ability to express in non-written form (15) presentation ability, (18) ability to make appropriate self-evaluation, (19) ability to make appropriate evaluation, (20) ability to make revision/ improvement". There were 203 of such items being listed. Based on these findings, cluster III can be summarized as "III. Awareness on gathering and expressing of information".

Cluster IV consists of 4 awareness which are “(14) explanation ability, (16) listening ability, (17) communication ability, (23) cooperation ability". There were 112 of such items being listed. Based on these findings, cluster IV can be summarized as "IV. Awareness on communication ability".

Next, in contrast to the above, we have conducted the cluster analysis by setting ability/awareness frequency as a variant, and activity items as the case. Based on such analysis, we were able to obtain 4 clusters (clusters 1 to 4 ) on useful activities.

Cluster 1 consists of 10 activities which are " 08 asking faculty members concerning report problems, 20 others, 13 using exercise problem answers as a study tool, 07 asking friends concerning report problems, 18 responding to recognition survey, 19 evaluating ability and awareness, 14 solving exercise problems by referring to example explanation, 16 solving report problems, 15 solving exercise problems by using text books, 17 writing down report discussion". Based on these findings, cluster 1 can be summarized as "1. Activities on solving problems and creating reports". There were 139 of such activity items being listed.

Cluster 2 consists of 4 activities which are "04 asking faculty members regarding lecture content, 06 asking faculty members regarding exercise problems, 03 asking friends regarding lecture content, 05 asking friends regarding exercise problems". Based on these findings, cluster 2 can be summarized as " 2 . Activities on asking questions regarding class contents". There were 166 of such activity items being listed.

Cluster 3 consists of 5 activities which are "09 study preparation, 10 study review, 11 studying by using text books, 12. studying by using lecture slide, 02 listening to exercise problem answers". Based on such analysis, cluster 3 can be summarized as "3. Activity on self-learning". There were 282 of such activity items being listed.

Cluster 4 consists of one activity which is " 01 listening to lecture". Based on these findings, cluster 4 can be summarized as " 4 . Activity on listening to lecture". There were 305 of such activity items being listed.

\subsection{Useful Activities in Improving Ability Related Awareness}

We totalize the frequency per cluster of awareness and activity, and display it on the top left corner of Table 4. The expectation frequency is displayed on the top right corner. We have conducted $\chi^{2}$ test by turning this table into contingency table of 
$4 \mathrm{X} 4$. The result showed a significant deviation on the frequency $\left(\chi^{2}(9)=136.6, p<.001\right)$. Because of this, based on the residual analysis result, we have placed a * mark on the positive residual cell within the cell considered significant. Such cell is shown on significance probability section on bottom right of Table 4.

From such analysis, we were able to understand that " 1 . Activities on solving problems and creating reports" has a useful tendency to increase "III. Awareness on gathering and expressing of information". We were able to understand that " 2 . Activities on asking questions regarding class content" is useful in increasing "IV. Awareness on communication ability". We were able to understand that "3. Activity on self-learning" is useful in increasing the "II. Awareness on learning and sense of satisfaction". We were able to understand that " 4 . Activity on listening to lecture" is useful in increasing "I. Awareness on understanding of OR and problem solving ability".

For this class, we were able to confirm that as the first step, lecturing on OR content by using slide is serving a useful purpose in understanding OR and increasing the problem solving ability. As the following step, we believe that after distributing the exercise problems and topic problems sheets, students have been solved such problems and drawnup reports have contributed to the increase of ability to be able to gather and express information. It seems that having students solve the problems on their own during class and having them solve the problems at home (if they cannot solve it during class) has actually made them feel a solid sense of learning, and has led to their sense of satisfaction and accomplishment. Asking questions to faculty members and other students concerning difficult problems helped them alleviate resistance toward acts of asking questions and carrying communication.

Table 4. Results of $\chi^{2}$ Analysis and Residual Analysis for Cross-Tabulation Table of Attitude and Activity Clusters

\begin{tabular}{|c|c|c|c|c|c|c|c|c|c|}
\hline \multirow[b]{2}{*}{$\begin{array}{c}\text { Clusters of atittude and } \\
\text { activities }\end{array}$} & \multicolumn{5}{|c|}{ Observed frequency } & \multicolumn{4}{|c|}{ Expected frequency } \\
\hline & 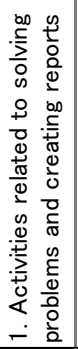 & 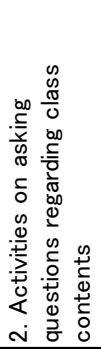 & 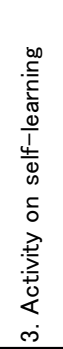 & 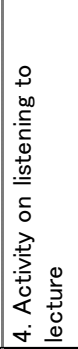 & $\begin{array}{l}\bar{\pi} \\
\stackrel{\Gamma}{\circ} \\
\vdash\end{array}$ & 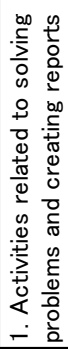 & 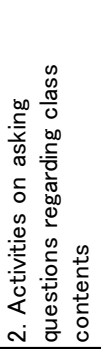 & 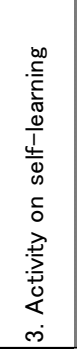 & 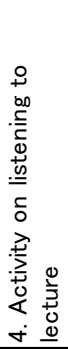 \\
\hline $\begin{array}{l}\text { I. Awareness on understanding of OR } \\
\text { and ability to solve problems }\end{array}$ & 61 & 47 & 124 & 168 & 400 & 62.3 & 74.4 & 126.5 & 136.8 \\
\hline $\begin{array}{l}\text { II. Awareness on learning and sense of } \\
\text { satisfaction }\end{array}$ & 28 & 27 & 78 & 44 & 177 & 27.6 & 32.9 & 56.0 & 60.5 \\
\hline $\begin{array}{l}\text { III. Awareness on gathering and } \\
\text { expressing of information }\end{array}$ & 41 & 30 & 64 & 68 & 203 & 31.6 & 37.8 & 64.2 & 69.4 \\
\hline IV. Awareness on communication ability & 9 & 62 & 16 & 25 & 112 & 17.5 & 20.8 & 35.4 & 38.3 \\
\hline \multirow[t]{2}{*}{ Total } & 139 & 166 & 282 & 305 & 892 & 139 & 166 & 282 & 305 \\
\hline & \multicolumn{4}{|c|}{ Adjusted residual } & & \multicolumn{4}{|c|}{ Significance probability } \\
\hline $\begin{array}{l}\text { I. Awareness on understanding of OR } \\
\text { and ability to solve problems }\end{array}$ & -0.2 & -4.7 & -0.3 & 3.9 & & & & & $* * *$ \\
\hline $\begin{array}{l}\text { II. Awareness on learning and sense of } \\
\text { satisfaction }\end{array}$ & 0.1 & -1.2 & 3.3 & -2.4 & & & & $* * *$ & \\
\hline $\begin{array}{l}\text { III. Awareness on gathering and } \\
\text { expressing of information }\end{array}$ & 1.9 & -1.4 & 0.0 & -0.2 & & + & & & \\
\hline IV. Awareness on communication ability & -2.2 & 9.6 & -3.5 & -2.3 & & & $* * *$ & & \\
\hline
\end{tabular}

\subsection{Categorization of Students Based on Cluster Analysis that uses Ability Awareness}

In difference (increase) between the pre- and post-rating value of the awareness related to ability, we have conducted the cluster analysis through Ward method by setting students as the case and awareness as variables for statistical table of 35 rows X 19 columns used in section 3.2. If we set the readjusted distant cluster combination into approximately 7 based on the obtained dendrogram, students are categorized into 4 clusters as shown on Figure 1.
Such clusters are classified as cluster 1 through 4. Horizontal axis of Fig.1 is dissimilarity, while vertical axis represents "students". The average elongation and standard deviation were 0.89 and 1.57 , respectively. In addition, the average rating value of general awareness items 1 to 30 and the average rating value of awareness items 31 to 35 related to subject were 0.67 and 2.22 , respectively. The comparison result of the significant difference verification is shown on Table 5 with respect to the rating value of general awareness and awareness related to subject. You can see the significant rise on 
the rating value of the general awareness and awareness related to subject for each group. Furthermore, you can see that rating value of awareness related to the subject for each group rises more significantly than the general awareness by looking at the result of verifying significant difference shown on the right corner of Table 5.

The group characteristic will be explained as follows. Group 1 consists of a student group with 7 people who did not show much change on their general awareness and awareness related to subject. Such group is named "S1: Group showing small change in general awareness and awareness related to subject".

Group 2 consists of a student group with 5 people that showed a small rise of general awareness rating value, along with showing of above average rise in their awareness related to subject. Such group is named "S2: Group showing small rise in general awareness and rise in awareness related to subject".

Group 3 consists of only one person that showed a decline on the rating value of general awareness. However, since this student shows a significant rise on the awareness related to subject, we name such person "S3: Group showing decline in general awareness and significant rise in awareness related to subject".
Group 4 consists of a student group with 6 people that showed a significant rise in both general awareness and awareness related to subject. Such group is named "S4: Group showing significant rise in general awareness and awareness related to subject".

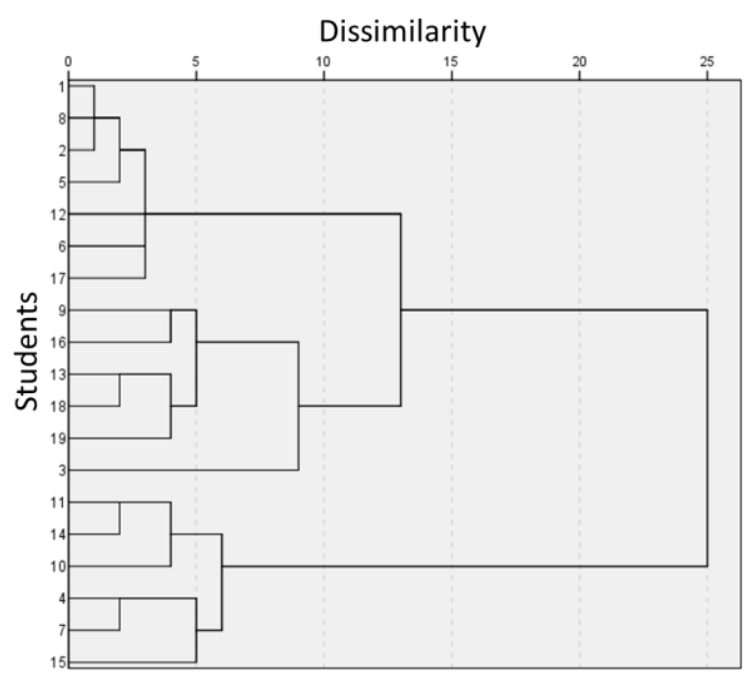

Figure 1. Categorization of Students Based on Cluster Analysis that uses Ability Awareness

Table 5. Comparison Between General Awareness and Awareness Related to Subject

\begin{tabular}{|c|c|c|c|c|c|c|c|c|c|c|c|c|c|}
\hline \multirow{2}{*}{ Group name } & \multirow{2}{*}{$\begin{array}{c}\text { No. of } \\
\text { students }\end{array}$} & \multicolumn{4}{|c|}{ General awareness } & \multicolumn{4}{|c|}{ Subject awareness } & \multicolumn{2}{|c|}{ Total } & \multicolumn{2}{|c|}{ Gen. \& Sub. } \\
\hline & & $\mathrm{m}$ & SD & $t$ & $\mathrm{p}$ & $\mathrm{m}$ & SD & $\mathrm{t}$ & $\mathrm{p}$ & $\mathrm{m}$ & SD & $\mathrm{t}$ & $\mathrm{p}$ \\
\hline S1: Small change in general awareness/awareness related to subject & 7 & 0.12 & 1.04 & 1.7 & + & 0.46 & 0.84 & 2.9 & ** & 0.17 & 1.02 & & * \\
\hline S2: Small rise in general awareness/rise in awareness related to subject & 5 & 0.77 & 1.29 & 8.3 & $* * *$ & 2.88 & 1.39 & 11.9 & $* * *$ & 1.07 & 1.50 & 6.9 & **** \\
\hline S3: Decline in general awareness/significant rise in awareness related to subject & 1 & -0.87 & 1.43 & 3.9 & *** & 3.60 & 0.80 & 8.0 & *** & -0.23 & 2.07 & 9.3 & $* * *$ \\
\hline S4: Significant rise in general awareness/awareness related to subject & 6 & 1.48 & 1.40 & 16.7 & **** & 3.50 & 1.26 & 16.8 & $* * *$ & 1.77 & 1.55 & 7.9 & $* * *$ \\
\hline Total & 19 & 0.67 & 1.41 & 13.4 & $* * *$ & 2.22 & 1.78 & 16.1 & $* * *$ & 0.89 & 1.57 & 8.0 & $* * *$ \\
\hline
\end{tabular}

\subsection{Principal Component Analysis on Awareness}

In finding out the characteristic of individual factors per each group, we have sorted awareness into groups by using the elongation of rating value. In specifics, we have conducted principal component analysis through correlation matrix method by using the elongation calculated from difference between pre- and post-rating value on awareness related ability shown in 35 items of Table 3 . The post-extract load of principal components 1 and 2 were $35.6 \%$ and $14.0 \%$, respectively. The cumulative load for such components was $49.6 \%$.

Since the coefficients of awareness for component 1 are between -0.11 and 1.57 and only 2 items are minus with small coefficient, we believe that coefficients of component 1 are the variable synthesizing all items. Based on these findings, component 1 is called "overall ability in trying to solve OR related problems". Furthermore, the coefficients of component 2 awareness are between 1.07 and 1.03. For component 2, factors such as
“(28) ability to think by yourself, (26) ability to solve problems, (17) ability to communicate, (30) interest/concern regarding this area" were considered a large coefficient with plus value, while "(33) knowledge to be able to express social issues in mathematical model, (32) knowledge on decision making method, (34) knowledge on algorithm used to solve mathematical model, (35) desire to solve social issues, (31) knowledge on Operations Research" were considered a large coefficient with minus value. Based on these findings, we will call the positive direction the "ability to be able to solve problems by own self through communication", and will call the negative direction the "ability in attempting to solve OR related problems". We believe that rating value of OR related awareness can be explained by these two components. 


\subsection{Categorization of Awareness through Principal Component Analysis Pertaining to Awareness Rating Value}

Through the conducting of cluster analysis by converting principal component score obtained in section 3.6 as coefficient pertaining to the elongation of rating value, 35 target awareness items has been categorized into 4 clusters (groups). 4 groups are shown on Figure 2 by using the score of principal components 1 and 2 .

The 3 items belonging to group 1 (G1, ○ mark) are shown on right corner. The average elongation is 2.5 and is the highest among 4 groups. Since it is categorized under 3 items pertaining to knowledge which are (32) knowledge on decision making method, (31) knowledge on operations research, and (34) knowledge on algorithm used to solve mathematical model, it is called a group of "knowledge on OR".

Group 2 (G2, $\square$ mark) is shown as 10 items on center left. The average elongation was 0.67 , and the average elongation of each items were between 0.16 and 1.05. These question items did not have much elongation with their average elongation being less than the overall average. Items that elongated more than 1 are the following 3 items: (17) ability to communicate $(\mathrm{m}=1.1),(22)$ ability to perform $(\mathrm{m}=1.1)$, and $(23)$ ability to cooperate $(\mathrm{m}=1.1)$. Based on these findings, we will call the group of "performance ability through cooperation and communication".

Group 3 (G3, $\Delta$ mark) is shown as 9 items on the center top. The average elongation was 1.03 , and the average rating value of each items were between 0.53 and 2.3. This is a group with second highest average elongation. In this group, the following 4 items had more elongation than 1: (33) knowledge to be able to express social issues in mathematical model $(\mathrm{m}=2.3)$, (35) desire to solve social issues $(\mathrm{m}=1.5)$, (14) ability to explain $(\mathrm{m}=1.1)$, and (24) sense of satisfaction $(m=1.1)$. Based on these findings, this group is called the group of "desire in attempting to express and solve social issues and sense of satisfaction".

Group 4 (G4, $\times$ mark) is shown as 13 items at the bottom. The average elongation was 0.6 and average elongation for each items were between 0.2 and 0.9 . All of the items showed less elongation than 1 . Within such items, the items that showed comparatively large elongation were "(28) ability to think by yourself $(\mathrm{m}=0.9)$, (27) ability to construct knowledge $(\mathrm{m}=0.9), \quad(2)$ ability to comprehend computer $(\mathrm{m}=0.8)$, and $(4)$ computer use method and scene expansion $(\mathrm{m}=0.7)$ ". Based on these findings, this group is called the group of "ability to create knowledge by expanding computer comprehension and thinking process".
Based on the variance analysis result of the average elongation of 4 groups, the effect of condition was shown to be significant $(F(3,661)=26.0, p<.001)$. Since multiple comparison has been conducted through Tukey method, such result is shown on Table 6 . There was a significant difference between group $\mathrm{G} 1$ and $\mathrm{G} 2$, between group G1 and G3, between group G1 and G4 respectively. There was a significant difference between group G2 and G3. In addition, a significant difference was shown between group G3 and G4. Based on these findings, we have discovered that group "G1: knowledge on OR" had larger elongation than "G2: performance ability through cooperation and communication", "G3: desire and sense of satisfaction in attempting to express and solve social issues" and "G4: ability to create knowledge by expanding computer comprehension and thinking process". We have discovered that group "G3: desire and sense of satisfaction in attempting to express and solve social issues" had larger elongation than group G2 or G4. Aside from these groups, no significant differences were found between other groups. Based on these results, the finding showed that OR related knowledge and desire which this class aims to accomplish had greater elongation than other awareness.

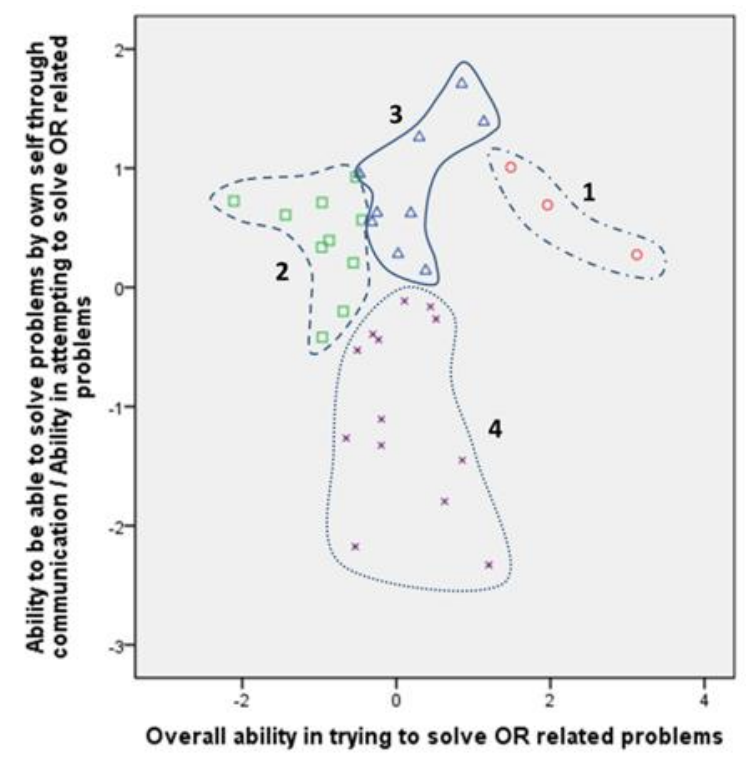

Figure 2. Groups of Awareness Item Expressed on the Plane of Two Components 
Table 6. Mean Elongation and Results of Multiple Comparison in each Group of Awareness

\begin{tabular}{|l|c|c|c|c|c|c|}
\hline \multicolumn{1}{|c|}{ Group } & No. of & \multirow{2}{*}{ items } & $\mathrm{m}$ & SD & \multicolumn{3}{c|}{ Multiple comparison } \\
\cline { 5 - 8 } & 3 & 2.46 & 1.86 & G.2 & G.3 & G.4 \\
\hline G1: Knowledge on OR & 10 & 0.67 & 1.55 & -- & $<$ & $=$ \\
\hline $\begin{array}{l}\text { G2: Performance ability through cooperation and } \\
\text { communication }\end{array}$ & 9 & 1.03 & 1.45 & -- & -- & $>$ \\
\hline $\begin{array}{l}\text { G3: Desire in attempting to express and solve } \\
\text { social issues and sense of satisfaction }\end{array}$ & 13 & 0.60 & 1.35 & -- & -- & -- \\
\hline $\begin{array}{l}\text { G4: Ability to create knowledge by expanding } \\
\text { computer comprehension and thinking process }\end{array}$ & 35 & 0.89 & 1.57 & -- & -- & -- \\
\hline \multicolumn{1}{|c|}{ Total } & $: \mathrm{Gn}\rangle \mathrm{Gm},\langle: \mathrm{Gn}\langle\mathrm{Gm},=: \mathrm{ns}$ \\
\hline
\end{tabular}

\section{Conclusion}

After a detailed explanation of the example solution, practice problem sheets with a framework for filling in the blanks with numerical values and results are distributed and practice is conducted. Challenges are conducted after explanation of the solution the following week. The effects of the class method focusing on practice were reported. The most frequent activities that helped with development were: listening to the lecture and the explanation of answers, preparation for and revision of lessons, and asking questions, etc. The following was discovered through an analysis of educational information that was gained from this class.

(1) Term recognition improved overall after the course. All 29 terms, not including the check terms, had improved after the course.

(2) Awareness related to ability improved overall after the course. The 20 awareness categories out of the total 35 categories improved after the course. In particular, the 5 categories for awareness related to OR class contents all improved.

(3) "Activities on solving problems and creating reports" has a useful tendency in improving "Awareness on gathering and expressing of information." "Activities on asking questions regarding class content" is useful in improving "Awareness on communication ability." "Activity on self-learning" is useful in "Awareness on learning and sense of satisfaction." "Activity on listening to lecture" is useful in "Awareness on understanding of OR and problem solving ability."

(4) When looking at 4 student groups obtained from the cluster analysis conducted through the use of awareness rating value, all such groups have shown a significant rise on the awareness rating value related to general awareness and awareness related to the subject.

(5) All of the student groups have shown a greater significant increase on the awareness rating value related to this subject when compared to general awareness.

(6) Based on 4 awareness groups obtained from the cluster analysis conducted through the use of awareness rating value, the finding showed that knowledge and desire on OR which are aimed by this class had greater elongation when compared to other awareness.
Students submitted practice problem and challenge problem sheets several times until they got the right answers. We would like to study the effects of this in the future. In addition, we would like to be more inventive with the practice methods and research the role of media in further improving effects.

The author appreciates the support of the Grantin-Aid for Scientific Research, foundation study (C25350364) provided by the Ministry of Education, Culture, Sports, Science and Technology, Japan for this research. The author would like to express appreciation to the students who were surveyed and who helped collect educational information.

\section{References}

[1] I. Miyaji, Operations Research Learned by Exercises, Kyouritu-Shuppan, Tokyo, Japan, 2008.

[2] I. Miyaji, "Class of the Operations Research to Conduct Practice Mainly with a Calculator", Spring Proceedings of the Operations Research Society of Japan, Tsukuba, 2009, pp.274-275.

[3] K. Adachi, "Analysis of the Classification of the Learners' Activities in Blended Learning", Japan Journal of Educational Technology, vol.31, no.1, 2007, pp.29-40.

[4] J. Bersin, The Blended Learning Book: Best Practices, Proven Methodologies, and Lessons Learned, Pfeiffer, San Francisco, USA, 2004.

[5] T. Nishimori, et al., "Development of the E-learning System Cooperating with Lessons in Classrooms of Higher Education", Japan Journal of Educational Technology, vol.27, Suppl., 2003, pp.9-12.

[6] T. Mochizuki, et al., "Analysis of Student Evaluation of E-learning Programs Cooperated with Campus Classrooms", Transactions of Japanese Society for Information and Systems in Education, vol.20, no.2, 2003, pp.132-142.

[7] Japan E-learning Consortium (Non Profit Organization) (Ed.), E-learning White Paper 2008/2009, Tokyo Denki University Press, 2008, pp.58-83.

[8] I. Miyaji (Ed.), Toward Blended Learning from Elearning, Kyouritu-Shuppan, Tokyo, Japan, 2009.

[9] Central Education Council, "For Construction of College Program Education (report)", http://www.mext.go.jp/bmenu/shingi/chukyo/chukyo0/tous hin/1217067.htm (Retrieved: 10 Oct. 2008).

[10] I. Miyaji and K. Yoshida, "The Pactice and Larning Efect of Eucation by Bending of Leture and E-learning", Transactions of Japanese Society for Information and Systems in Education, vol.22, no.4, 2005, pp.230-239.

[11] I. Miyaji, K. Yoshida, and Y. Naruse, "Effects of Blending E-learning and Lectures Utilizing a Structured Notebook", Transactions of Japanese Society for 
Information and Systems in Education, vol.24, no.2, 2007, pp.208-215.

[12] I. Miyaji, "Effects on Blended Class Which Incorporates E-learning Inside the Classroom", Proceedings E-learn2009, The 20th World Conference on E-Learning in Corporate, Government, Healthcare \& Higher Education, Vancouver, 2009, pp.1818-1826.

[13] I. Miyaji, "Comparison between Effects in Two Blended Classes Which E-learning is Used inside and outside Classroom", US-China Education Review, USA, vol.8, no.4, 2011, pp.468-481.

[14] Y. Nakamura, H. Kojima, and M. Kikugawa, "Measurement of Basic Knowledge about Information Technology Using Questionnaire on Computer Technical Terms, and its Application to Evaluation of Information Education", Information Processing Society of Japan Journal, vol.45, no.4, 2004, pp.1222-1231. 